\title{
Annual cockle Cerastoderma edule production in the Wadden Sea usually fails to sustain both wintering birds and a commercial fishery
}

\author{
J. J. Beukema*, R. Dekker \\ Royal Netherlands Institute for Sea Research, PO Box 59, 1790 AB Den Burg, Texel, The Netherlands
}

\begin{abstract}
Low cockle Cerastoderma edule stocks in the Dutch Wadden Sea over the last $\sim 15 \mathrm{yr}$ have caused ecological problems, including declines in numbers of some specialized bird species and a sharpening conflict between nature conservationists and fishermen. To study why cockle production and resulting biomass of adult cockles failed, we analyzed long-term (1973 to 2003) data on annual and cohort production of cockles in the Balgzand tidal flat area in the westernmost part of the Wadden Sea. Somatic production was estimated from summed growth increments per half-year period and expressed in ash-free dry weight (AFDW). In adults, positive values in April to August regularly alternated with negative values in September to March, when up to $60 \%$ of individual weight gains in the preceding season were lost. Life-time production averaged $0.06 \mathrm{~g}$ AFDW for $\sim 3$ mo old recruits and $0.21 \mathrm{~g}$ for $\sim 10$ mo old recruits. The numerical recruit density of a cohort as observed after their first winter predicted subsequent life-time cohort production within narrow lim-

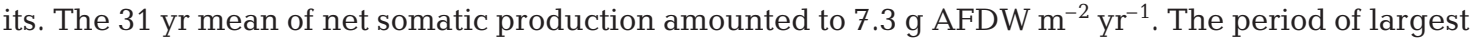
production during the lifetime of a cohort occurred during their second growing season (when cockles grow from spat to adult size). Years with high production values occurred 1 yr after a highly successful reproductive season, and high biomasses were achieved 1 to 3 yr after a highly successful season. In contrast, low values were observed when a successful recruitment had been $>3 \mathrm{yr}$ in the past, and also after severe winters (causing high cockle mortality). Local variation in mean annual production was primarily related to local variation in recruitment success; however, production per recruit was significantly higher at low than at high intertidal levels. The main cause of low biomass values observed in recent years was failing recruitment in off-shore areas. As a consequence, in nearly all of the last 15 years, cockles have been too scarce in the western Wadden Sea to sustain both wintering birds and a commercial fishery.
\end{abstract}

KEY WORDS: Long-term data $\cdot$ Seasonal growth $\cdot$ Annual recruitment $\cdot$ Secondary production $\cdot$ Tidal flats

\section{INTRODUCTION}

To characterize a species' role in ecosystem functioning, it may be more relevant to investigate its (mean) annual production rather than its contribution to numbers or biomass. Because such characteristics tend to vary temporally and spatially, studies aimed at obtaining representative estimates should be of a long-term and multi-station character. In practice, however, the vast majority of published results of productivity studies in marine invertebrates do not fulfill these conditions.

The availability of a long-term (1973 to 2003) data series on macrozoobenthos, sampled biannually at 15 stations scattered over an extensive $\left(50 \mathrm{~km}^{2}\right)$ area, offers an opportunity to study both year to year and station to station variability in annual production of a number of benthic species. As a start, we chose the 
cockle Cerastoderma edule (L., 1758) for a number of reasons.

Cockles play an important role in the ecosystem of the tidal flats of the Wadden Sea, ranking 4th in their contribution (on average 16\%) to total zoobenthic biomass of the Dutch Wadden Sea (Beukema 1976). Together with blue mussels Mytilus edulis, they constitute the main food item of the 2 (quantitatively) most important bird species of the Wadden Sea: oystercatcher Haematopus ostralegus and eider Somateria mollissima. In some years, the cockle fishery also removed a substantial part of the available cockle stock. Low cockle stocks (as sometimes occur after consecutive years of low cockle reproduction, or after a mass mortality during a severe winter) are reported to be a significant cause of extra mortality in the above-mentioned bird species due to food shortage (Camphuysen et al. 1996, 2002). Incidences of mass mortalities of these bird species were one of the main motivations for the government of The Netherlands to stop most commercial exploitation of cockle stocks in the Dutch part of the Wadden Sea (Ens et al. 2004).

The magnitude of cockle production in any year depends (by definition) on their growth rates and numbers during the growing season, and thus ultimately on the success of recruitment in preceding years (and an absence of subsequent mass mortality). For cockle populations in the Wadden Sea, annual recruitment in particular varies widely from place to place and from year to year (Beukema 1982, Beukema et al. 2001, Strasser et al. 2003, Beukema \& Dekker 2005). As a consequence, the cockle is among the species that experience the highest fluctuations in annual biomass on Wadden Sea tidal flats (Beukema et al. 1993). So far, nearly all studies on annual flesh production in cockle populations were short-term (mostly 1 to $3 \mathrm{yr}$ ) and referred to limited numbers of sampling stations (mostly 1 to 3 ). Therefore, it is difficult to determine whether published production estimates (varying from $<1$ to $>100 \mathrm{~g}$ ash-free dry weight [AFDW] $\mathrm{m}^{-2} \mathrm{yr}^{-1}$ ) can be used as representative values.

The primary aim of the present study was to gain some knowledge about variability of cockle production, in order to judge how extensive (in terms of time and space) such a study should be to yield representative and unbiased estimates of cockle production. Furthermore, we studied to what extent contributing factors (such as recruit numbers and life-time production per recruit) affect annual and local production values. Finally, obtained series of estimates of annual cockle production and resulting biomass were compared to food requirements of oystercatchers, to assess whether a sustainable cockle fishery is possible on the tidal flats of the Dutch Wadden Sea.

\section{MATERIALS AND METHODS}

Since the early 1970 s, the macrozoobenthos community has been monitored at 15 fixed sampling sites (12 transects $1 \mathrm{~km}$ long, and 3 squares $30 \times 30 \mathrm{~m}$ ) (Fig. 1) at a $50 \mathrm{~km}^{2}$ tidal-flat area called 'Balgzand', in the westernmost part of the Dutch Wadden Sea $\left(\sim 53^{\circ} \mathrm{N}\right.$ and $5^{\circ} \mathrm{E}$ ). The monitoring program comprised biannual (late winter: mostly March, and late summer: mostly August) estimates of numbers and biomass of all macrobenthic animal species (size class: those retained on $1 \mathrm{~mm}$ sieves). Details on sampling sites and methods can be found in earlier publications (e.g. Beukema \& Cadée 1997). The sampling sites covered the entire intertidal depth range (Beukema \& Cadée

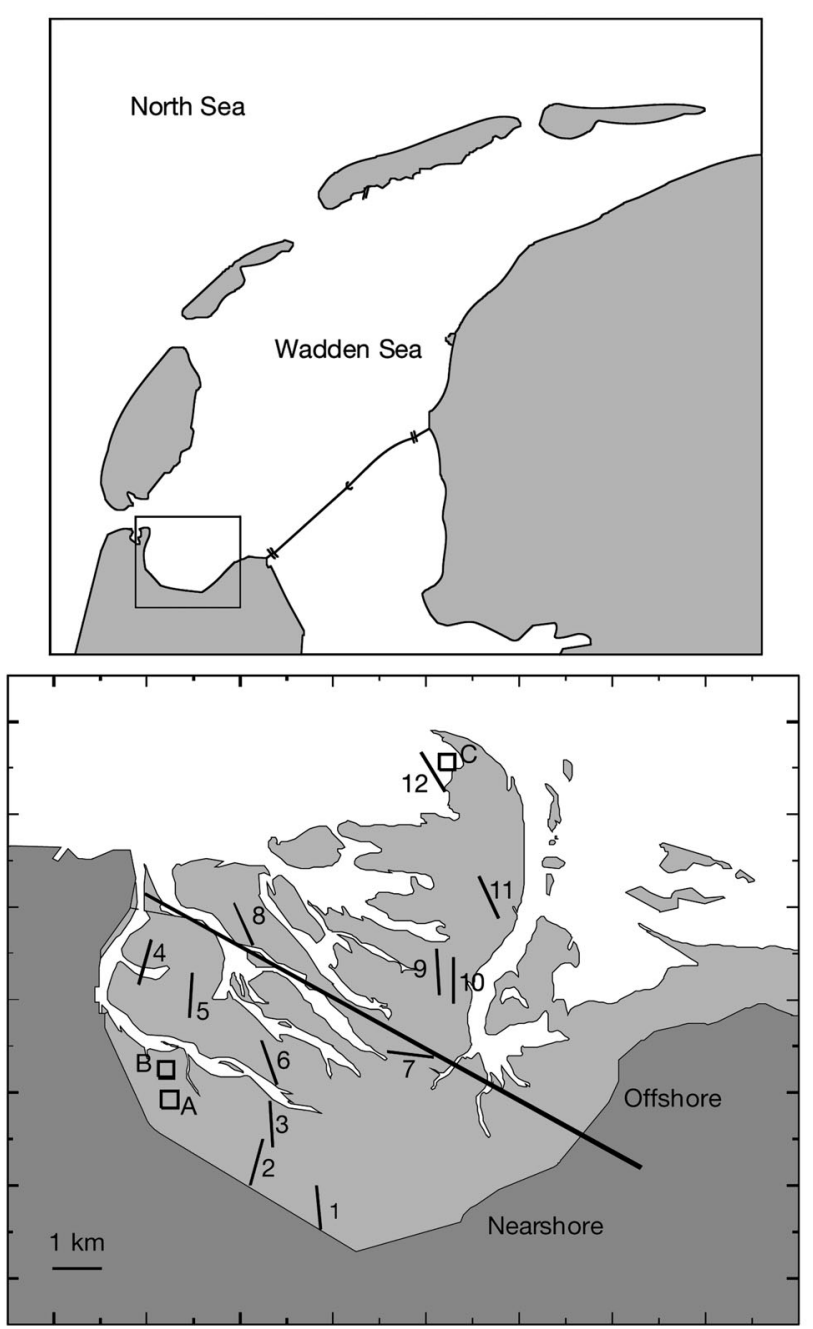

Fig. 1. (a) Location of Balgzand in the southwesternmost part of the Wadden Sea, and (b) detailed map of Balgzand, showing locations of the 15 sampling stations - 12 transects of 1 $\mathrm{km}$ and 3 squares of $900 \mathrm{~m}^{-2}$ (A, B, C). Heavy diagonal line demarcates the nearshore and offshore areas. Thin lines indicate borders between tidal flats and deeper waters 
1997 Fig. 1b), which runs on average from about +6 to $-8 \mathrm{dm}$, compared with mean-tide level (MTL). The level of near-shore sites is generally above MTL, and these sites are immersed for less than $50 \%$ of the time. The height of offshore sites decreases relative to the MTL with increasing distance from land, and the 2 farthest sites remain permanently immersed for more than half of the low tides. The sampling sites cover a wide range of sediment composition. The mud content (material $<60 \mu \mathrm{m}$ ) of the top $5 \mathrm{~cm}$ of the sediment ranges from $>10 \%$ near the southwest coast to $<1 \%$ in the most offshore parts of Balgzand.

Along each of the transects, 50 cores were taken at equal intervals $\left(20 \mathrm{~m}\right.$ ), covering a total of $0.45 \mathrm{~m}^{2}$ (summer) or $0.95 \mathrm{~m}^{2}$ (winter) per transect (18 to 32 samples were taken per square, covering 1 to $1.6 \mathrm{~m}^{2}$ ). In winter, larger samples were taken compared to summer, because numerical densities were generally lower in winter than in summer. In this study, we used data on cockles of the homogeneous 30 yr series (1973 to 2003). All data were expressed as follows: abundance $\mathrm{n} \mathrm{m}^{-2}$, biomass $\mathrm{g}$ AFDW $\mathrm{m}^{-2}$, and production $\mathrm{g}$ AFDW $\mathrm{m}^{-2}$ $\mathrm{yr}^{-1}$. All cockles were sorted from the sieved samples, assigned to age classes, measured, and opened by short immersion in boiling water to remove the soft parts. These were dried $\left(2\right.$ to $3 \mathrm{~d}$ at $60^{\circ} \mathrm{C}$ in a ventilated stove), weighed (individually or per $1 \mathrm{~mm}$ shell-length class), and incinerated. Ash weight was subtracted from dry weight to obtain AFDW.

Production $(P)$ was estimated following the weightincrement summation method, by summing the weight increments $\left(\Delta W=w_{t+1}-W_{t}\right)$ for any period (between $t$ and $t+1)$ of all the members of the population $\left(N_{t}\right.$ and $N_{t+1}$ are the numerical densities at the start and end of the production period, and half of their sum is the mean numerical density). Thus, $P=0.5\left(N_{t}+N_{t+1}\right) \times$ $\left(w_{t+1}-w_{t}\right)$, expressed in $g$ AFDW $\mathrm{m}^{-2} t^{-1}$. Separate estimates were made for half-year periods and for each of the 15 sites. To obtain annual estimates (March to March), we used the sum of 2 successive seasonal estimates, i.e. (mid) March to (mid) August (growing season with mostly positive values), and (mid) August to (mid) March (weight-loss season with mostly negative values). Estimates of $N$ and $w$ were obtained separately per year class (cohort: all individuals born in the same year), but the scarce cockles of $>4 \mathrm{yr}$ old were grouped together. Age determination was done by external examination of the number of year marks on the shell (for validation and precision, see Beukema 1989). Unless specified otherwise, the $P$ values shown are sums of all year classes present at one time with the exception of small spat-sized cockles of $<3$ mo old: we did not succeed in estimating cockle production during the first growing season. The first regular estimates of $N$ and $w$ in the life of the cockle cohorts were made in
August, 2 or 3 mo after their settlement in May or June (Beukema \& Dekker 2005).

We generally used actual observed values of $N$ and $W$, without smoothing or interpolating missing values. Only a few obviously incorrect density estimates of very small cockles were (minimally) adjusted. This was the case in some years $(1991,1992)$ at some (nearshore) sampling sites where very small ( 1 mm) spat were present in the August and subsequent March samples. Part of these small cockles were apparently overlooked, as higher numbers of members of these cohorts were found in subsequent August samples (when they had reached a size of 1 to $2 \mathrm{~cm}$ ). In these few cases, we used the higher estimates for the foregoing sampling periods.

A detailed study of seasonal growth rates was made by sampling the cockle population at approximately monthly intervals at 2 fixed stations along Transect 8 (Fig. 1). This population was composed of 4 age classes (born between 1975 and 1978, though cockles born in 1977 and 1978 were present at only 1 of the 2 stations). During the period March 1977 to April 1979, 10 samples of $0.1 \mathrm{~m}^{2}$ each were taken at each station. The sampling period included the first growing season of the cohorts born in 1977 and 1978, the second season of the 1977 and 1976 cohorts, the third season of the 1976 and 1975 cohort, and the fourth season of the 1975 cohort. At each sampling occasion and for each cohort, mean numerical density, mean length, mean dry shell weight, and mean AFDW were assessed. Full results are shown in Sager (1986). He describes the cockle soft-parts growth curve as a seasonally modified version of a Richards-function, because a modified Bertalanffy function could not be used. In this study we did not apply these formulae, but simply used the observed raw data. Values for mean AFDW for each month were obtained by simple linear interpolation of the actual data of 2 successive monthly samplings to the 15 th of each month. Abundance values $\left(\mathrm{n} \mathrm{m}^{-2}\right)$ at the 15th of each month were found by smoothing (by eye) of several successive density assessments before being used for estimating production. Monthly production estimates were calculated by the growth-increment method as above for the semi-annual estimates.

\section{RESULTS}

\section{Seasonal pattern of production}

At the 2 Balgzand stations where we studied production in detail, changes in weights of soft parts in cockles were positive in spring and summer, whereas weight losses predominated in autumn and winter (Fig. 2). Maximal weights of soft parts were observed 


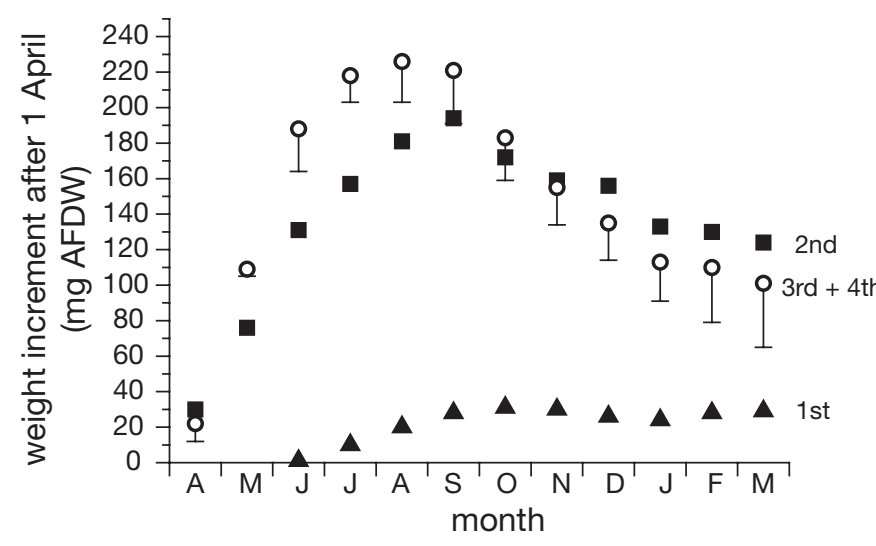

Fig. 2. Cerastoderma edule. Temporal changes in mean individual weight of soft parts (mg AFDW), expressed as the difference from mean weight at 1 April (Day 0) for each of 3 age groups: spat ( $\mathbf{\Delta}:$ 1st growing season, means of 2 data sets [1977 year class in 1977, and 1978 year class in 1978], 1 station), 1 yr ( $\square$ : 2nd growing season, means of 3 data sets [1977 year class in 1978 at 1 station, and 1976 year class in 1977 at 2 stations]), and older cockles (O: 3rd and 4th growing seasons, means of 6 data sets [1976 year class in 1978 at 2 stations, 1975 year class in 1977 at 2 stations, and 1975 year class in 1978 at 2 stations]). Means of the latter group with 1 SE ( $n=$ 6). Actual initial mean weights at Day 0 (set at 0 ) were 10 to $40 \mathrm{mg}$ at the start of the second growing season, and 150 to $\sim 250 \mathrm{mg}$ AFDW at the start of latter growing seasons (compare Sager 1986 Fig. 3)

in autumn or winter for cockles in their first growing season, in early autumn (second half of September or early October) in their second growing season, and in late summer (August to mid September) in later growing seasons (i.e. in older cockles). Subsequent weight losses (that were sustained until $\sim$ March of the next year) were small or absent after the first growing season, amounted to $\sim 40 \%$ after the second growing season, and increased to $\sim 65 \%$ of the preceding weight gain in later growing seasons.

At the 2 frequently sampled stations, cockle numbers generally and gradually declined in autumns and winters. However, 1 station was heavily fished for cockles in the second year (as visible from bottom traces and a sudden decline in cockle numbers), and therefore we did not use further data from this station for calculations of production. The remaining data sets for cockles during their second or later growing seasons showed positive mean production during each month of the 5 mo period from April to August, and negative mean production during the other months of the year (Fig. 3). In Fig. 3, the data are expressed as proportions of the annual average to reduce standard errors of monthly means (otherwise these would be large due to substantial differences in numerical densities among year classes and stations). Note that the mean production values in February to March and particularly in August
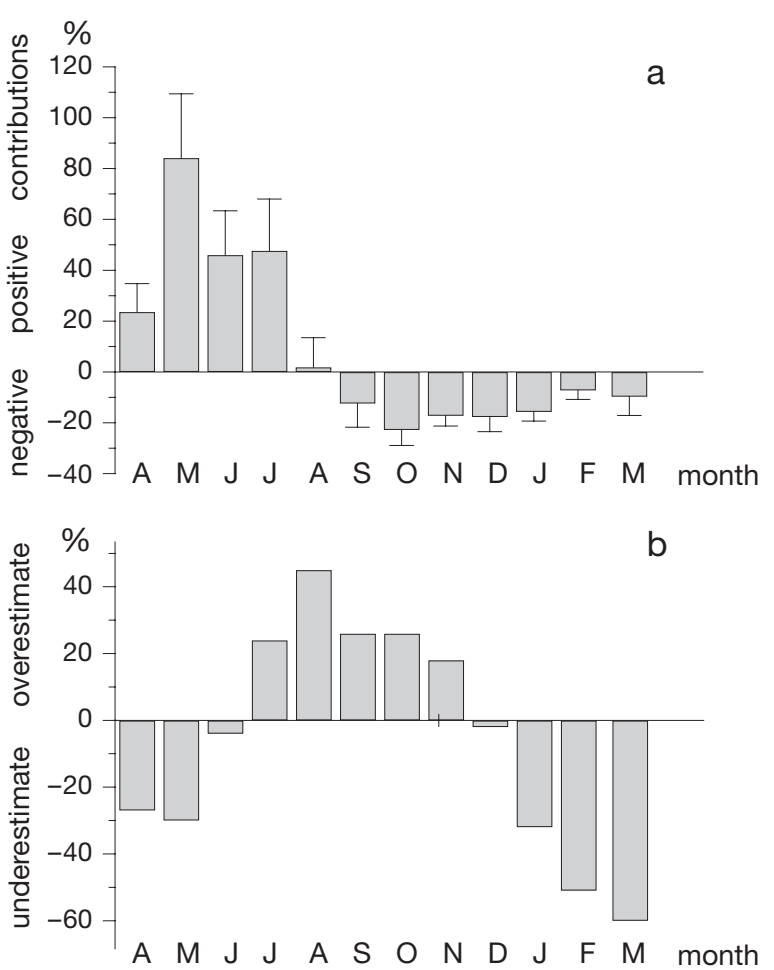

Fig. 3. Cerastoderma edule. (a) Mean monthly contributions to total annual production (growth-increments summation method) of cockles $>9$ mo old at 2 stations on Balgzand, expressed as a mean proportion (\%) of total net annual (April to March, inclusive) production. Means with 1 SE of 7 data sets: 1977 year class in 1978 (1 station), 1976 year class in 1977 (2 stations) and 1978 (1 station), and 1975 year class in 1977 (2 stations) and 1978 (1 station). Data of 1 station in 1978 omitted because fishery seriously reduced cockle numbers there. (b) Mean difference between estimates of annual production made by 2 methods: single estimates based on annual sampling in the month indicated at the $x$-axis, compared with reference values of 12 mo sums of the separate monthly estimates for the same periods. Differences expressed as a \% of reference values. Data used: monthly samples of the cockle cohort born in 1976, taken between March 1977 and March 1979 at 2 stations

were close to 0 . In these months, production values changed from negative to positive and vice versa.

At the 2 stations in the 2 years 1977 and 1978, the sum of the positive values (April to August, inclusive) was on average roughly double the annual net production (sum of all values from $12 \mathrm{mo}$ ). Therefore, in these years at these stations, on average no less than half of the production by growth increments was lost in the subsequent September to March periods.

\section{Optimal sampling for estimating production}

Precision of production estimates can be enhanced by an increase in frequency of sampling, in particular 
because rates of mortality are not constant within a production period, depending on factors such as fluctuating weather conditions and predation pressure. However, sampling at a rate of more than a few times per year is not practicable for such an extensive and heterogeneous area as the entire Balgzand. As a compromise, we decided that biannual sampling might be optimal, with samples taken around the annual times of minimal and maximal biomass, i.e. in March and in August, respectively. This procedure enables separate estimates of growing-season and total annual production. As shown above, these are the times of change from positive growth to weight loss and of close-to-0 values for monthly production of cockles (Figs. $2 \& 3 \mathrm{a}$ ). At these times of the year, rates of individual weight change were minimal (Fig. 2) and some inevitable variation in exact timing of sampling (e.g. from mid-February to early-April) would then have minimal effects on resulting estimates of mean weight (and thus of production).

As an estimate for annual production, we used the sum of 2 half-year estimates (the growing season March to August plus the subsequent August to March period when part of the preceding weight gains is lost). We preferred to define a year as a March to March period rather than as an August to August period, because an annual March to March estimate includes a weight loss that was part of the preceding weight gain, yielding a sensible net annual value (whereas an August-August estimate would include a loss of weight gained in the earlier production year).

A time-saving alternative of annual sampling at the start of the growing season (in March, as was conducted before 1973) is bound to result in underestimates of annual net production. The failure of annual sampling at either the start or the end of the annual growing season can best be explained by means of an Allen plot (Fig. 4). In such plots of successive paired (simultaneous) estimates of numerical density and individual weight (Crisp 1984), the area below the line connecting these co-ordinates equals production (=mean number of ind. $\times$ mean individual weight change). In the cockle population investigated in this study, densities declined particularly in autumn and winter (the apparent increases in summer were nonsignificant and resulted from sampling error), and weights declined in autumn/winter and increased in spring/summer (as shown in Fig. 2).

From Fig. 4, it is immediately clear that production values calculated from March density and weight estimates were much lower than those from August estimates (from areas below lines connecting March and August points, respectively). The true net annual production values are somewhere between the areas below lines connecting August points (indicated by 8)

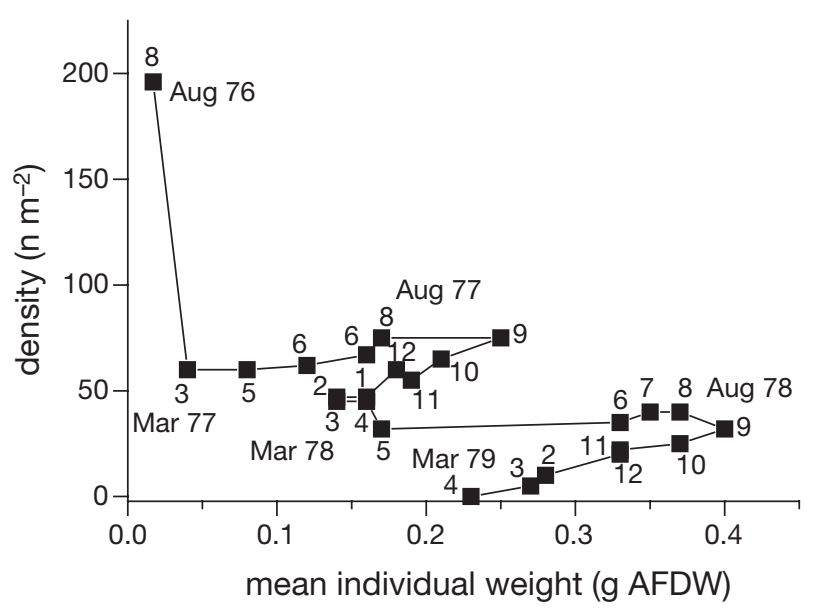

Fig. 4. Cerastoderma edule. Allen plot of simultaneous estimates of density $\left(\mathrm{n} \mathrm{m}^{-2}\right.$ ) and mean individual weight (g AFDW) of cockles belonging to the cohort born in 1976 and identified at successive ( monthly) samplings during August 1976 to March 1979. Means obtained from 2 stations. Sampling month indicated numerically (1: January ... 12: December)

and those connecting March points (indicated by 3), thus roughly the area below the line through June or December estimates. Apparently, sampling results obtained in either June or December could result in an unbiased estimate of net annual production by annual sampling. Results of a calculation exercise with a 2 yr series of monthly data on numerical density and mean individual weight showed more precisely that annual sampling in either June or in December would result in almost unbiased estimates of net annual production (because estimates are then similar to the sums of 12 monthly estimates for the same period) (Fig. 3b). We would not recommend a procedure of annual sampling because: (1) individual weights change rapidly in and around June (leaving a short window for sampling at that time), (2) different age classes did not show identical patterns in weight change (Fig. 2), and (3) annual sampling does not provide any insight into the composition of annual production with long seasonal periods of alternating positive and negative production.

To determine in practice whether our procedures based on biannual sampling provided unbiased estimates of net annual production, we compared these estimates with sums of 12 monthly estimates, using the data obtained at the 2 stations that were sampled approximately every month for 2 yr (i.e. data sets used to prepare Figs. $2 \& 3$, but in this case including the fishing years, resulting in a total of 9 pairs of values of annual net production). In 4 out of these 9 cases, the monthly-based values were higher than the half-yearbased estimates. The members of the 9 pairs were closely related. A linear fit through the origin yielded the following relationship: sum half-year estimates = 
$1.05 \times$ sum monthly estimates, with $r=0.93, p<0.0001$. The 1.05 factor was not significantly different from 1.0 (its error amounted to 0.11). Thus, our method of halfyear sampling appeared to produce unbiased estimates of annual production.

\section{Long-term changes in production}

The annual estimates of the 15 station means of softparts production of cockles (aged $>9 \mathrm{mo}$ ) within the 5 mo growing seasons between 1973 and 2003 varied markedly from 0 to $36 \mathrm{~g}$ AFDW m ${ }^{-2} \mathrm{yr}^{-1}$, with an average of $9.0 \pm 1.6 \mathrm{~g}$ AFDW m${ }^{-2} \mathrm{yr}^{-1}$ (31 $\mathrm{yr}$ mean with $1 \mathrm{SE}$ ). Likewise, annual net (spring/summer minus subsequent autumn/winter) production values varied markedly from 0 to $30 \mathrm{~g} \mathrm{AFDW} \mathrm{m}^{-2} \mathrm{yr}^{-1}$ (Fig. 5a), with a $31 \mathrm{yr}$ average of $6.8 \pm 1.3 \mathrm{~g} \mathrm{AFDW} \mathrm{m} \mathrm{m}^{-2} \mathrm{yr}^{-1}$. This mean value increased to $7.4 \mathrm{~g} \mathrm{~m}^{-2} \mathrm{yr}^{-1}$ if the (usually positive) production in the first winter half-year (August to March) was added. In subsequent winter half-year periods, cockles lost weight (Fig. 2) and winter contributions to annual production were negative. The long-term growing-season-only estimate thus overestimated net annual production by $\sim 30 \%$ of the long-term net annual value. In accordance with the proportional autumn/winter weight loss that increased with age of the cockles (compare Fig. 2), this percentage also increased with age, from $24 \%$ in the year that included the second growing season, to $38 \%$ in the year that included the third growing season, to $61 \%$ in years thereafter.

The mean values for the 3 successive 10 yr estimates (shown in Fig. 5a) did not differ significantly ( $t$-test, $\mathrm{p}>$ 0.05), nor was the (declining) long-term trend of the 31 successive estimates for total Balgzand significantly different from 0. However, in the off-shore half of Balgzand (see Fig. 1), a statistically negative trend was observed (see end of 'Results') and this was the most important part of Balgzand for cockle production.

Production estimates differed greatly among years (Fig. 5a). This means that a short study, covering only part of the 30 yr period, would have yielded a mean value with wide confidence limits and, more importantly, could have been far from the long-term average. This would be particularly erroneous if short-term means had included only the first 1, 2, or 3 yr of observation since the initation of monitoring in 1973 (Fig. 5b). It was only some 10 or 15 yr after the start of the observations in 1973 that the long-term average stabilized (more or less).

To study how many years of observation would be required to reach a certain precision with the present variability as shown in Fig. 5a, we calculated in a cumulative manner mean values for series of increas-
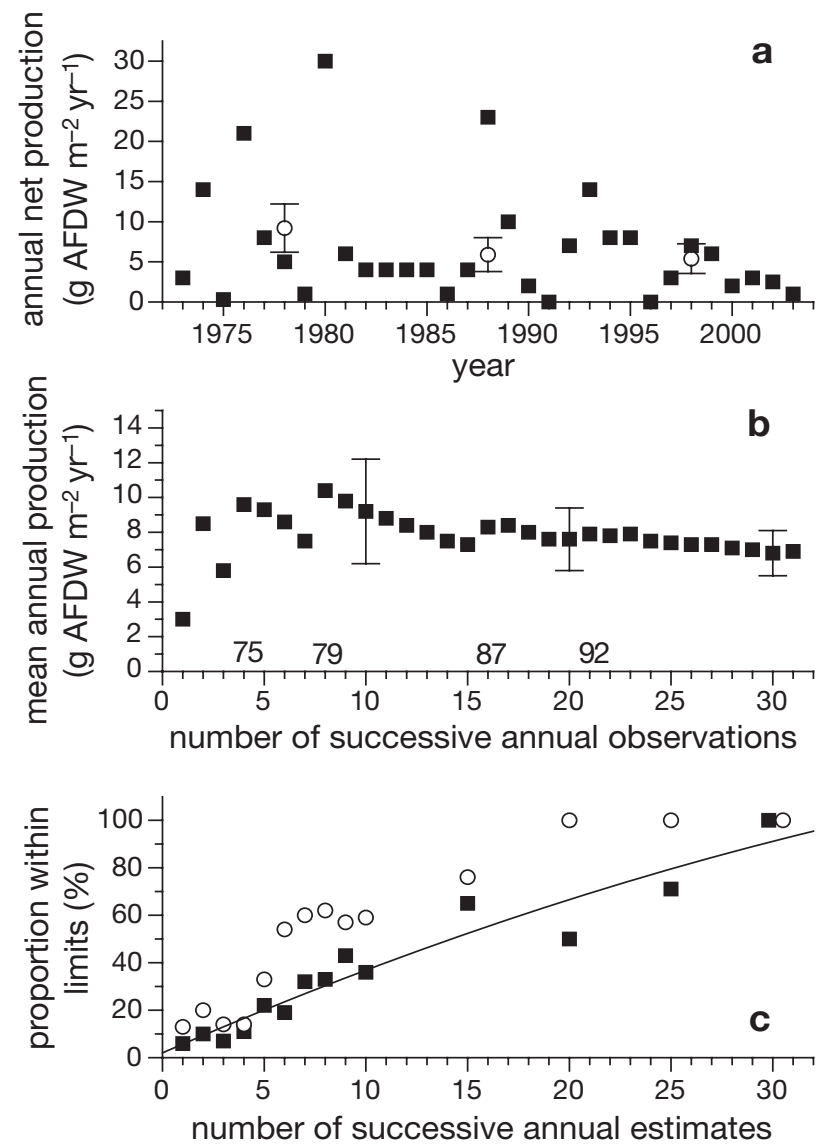

Fig. 5. Cerastoderma edule. (a) $\mathbf{\square}$ : Separate successive annual (1973 to 2003) estimates of net somatic production (g AFDW $\mathrm{m}^{-2} \mathrm{yr}^{-1}$; April to March, inclusive) of soft parts of all cockles $>9$ mo old on Balgzand (15-station means). O: Average values for 3 successive $10 \mathrm{yr}$ periods (1 SE); (b) Successive calculated cumulative means of annual values shown in (a) after $1,2, \ldots$, $31 \mathrm{yr}$ of observation. SE values calculated for means of 10, 20, and 30 annual estimates. Times of appearance in the cumulative means of the 4 strongest cohorts (born in 1975, 1979, 1987, and 1992) indicated; (c) Percentages (Pc) of estimates within the limits of $10 \%(\mathbb{\square})$ or $20 \%(\mathrm{O}) \pm$ the long-term average of all 31 annual estimates shown in (a) when using $N$ $(1,2,3, \ldots, 30)$ successive values of annual production ( $x$-axis). Polynomial fit added for $\mathbf{\square}$ : $\mathrm{PC}_{\mathrm{C}}=2.0+3.74 N-0.03 N^{2}$ $\left(r^{2}=0.92, p<0.0001\right)$

ing numbers of successive years, and compared these averages with the long term average of $6.8 \mathrm{~g} \mathrm{~m}^{-2} \mathrm{yr}^{-1}$ to see whether they differed $<10$ or $<20 \%$ from this value. With 31 individual estimates, there were 30, 29, $28, \ldots, 2$ series including $2,3,4, \ldots, 30$ successive annual estimates. The proportion of series averages within the stated limits increased with increasing number of estimates within the series (Fig. 5c), reaching $100 \%$ after about $20 \mathrm{yr}$ in the case of $\pm 20 \%$, and $30 \mathrm{yr}$ in the case of the narrower limit of $10 \%$. The increases up to these points were almost linear. The rate of increase was such that about $15 \mathrm{yr}$ of observation 
would be needed to have a $>50 \%$ chance of finding a mean value deviating not more than $10 \%$ from the long-term mean (Fig. 5c). A relaxation of the deviation to $20 \%$ would roughly halve this period.

Note in Fig. 5b the sharp increases of the cumulative means as soon as the contributions of 1976 and 1980 were included; these represented the production of the second growing season of the exceptionally strong year classes born in 1975 and 1979, respectively. Increases caused by the introduction of second growing season production of the similarly strong cohorts born in later years (i.e. those of 1987 and 1992) were subdued by the high number of observations that were already included in the mean value at that time. Averages calculated after 10,20, or $30 \mathrm{yr}$ of observation did not differ significantly ( $t$-test, $\mathrm{p}>0.05$ ). The SE values declined from 32 to $18 \%$ of the mean, reflecting the increase of $N$ at roughly unchanged values of $\mathrm{SD}$ (being close to the mean in all 3 cases) and variance (F-ratio of variances at 10 compared to 20 and 30 observations amounted to 1.4 and 1.7 , respectively, p > 0.05).

Together, the 4 outstanding production values $(>25 \mathrm{~g}$ $\mathrm{m}^{-2}$, Fig. 6) observed in the cohorts born in 1975, 1979, 1987, and 1992 accounted for more than half ( $60 \%)$ of the total cockle production in the 1973 to 2003 period. These 4 year classes were characterized by large numbers of juvenile cockles at the start of their second growing season (March numbers of recruits in the years 1976, 1980, 1988 and 1993 amounted to 118, 150, 192 , and $141 \mathrm{~m}^{-2}$, respectively), whereas in the remaining $27 \mathrm{yr}$ numerical densities of cockles of this age were between 0 and $50 \mathrm{~m}^{-2}$ (Fig. 6c).

Year classes that were strong from the beginning of their benthic life (i.e. showing high recruit numbers already at the first sampling occasion in August) produced on average significantly more cockle flesh than initially small cohorts did (Fig. 6b: Spearman $r=0.81$, $\mathrm{n}=30, \mathrm{p}<0.001$ ). Life-time production per August recruit (as determined subsequently) amounted to an average of $0.064 \mathrm{~g}$ AFDW. This is an order of magnitude less than maximal weights of soft parts. Low survival rates, particularly in the first winter of their life, prevented substantial production in the overwhelming majority of individual recruits. Once a recruit had survived its first winter, its subsequent production became more predictable: on average $0.21 \mathrm{~g}$ AFDW per March recruit (note the low scatter around the best-fit line in Fig. 6c). Recruit densities in March (at an age of almost $1 \mathrm{yr})$ were thus closely related to cohort production (Spearman $\mathrm{r}=0.97, \mathrm{n}=30, \mathrm{p}<0.0001$ ) and explained $>90 \%$ of variability in subsequent cohort production (regression analysis). Due to the erratic and often high mortality over the first winter, August numbers of recruits were less closely (though still significantly)
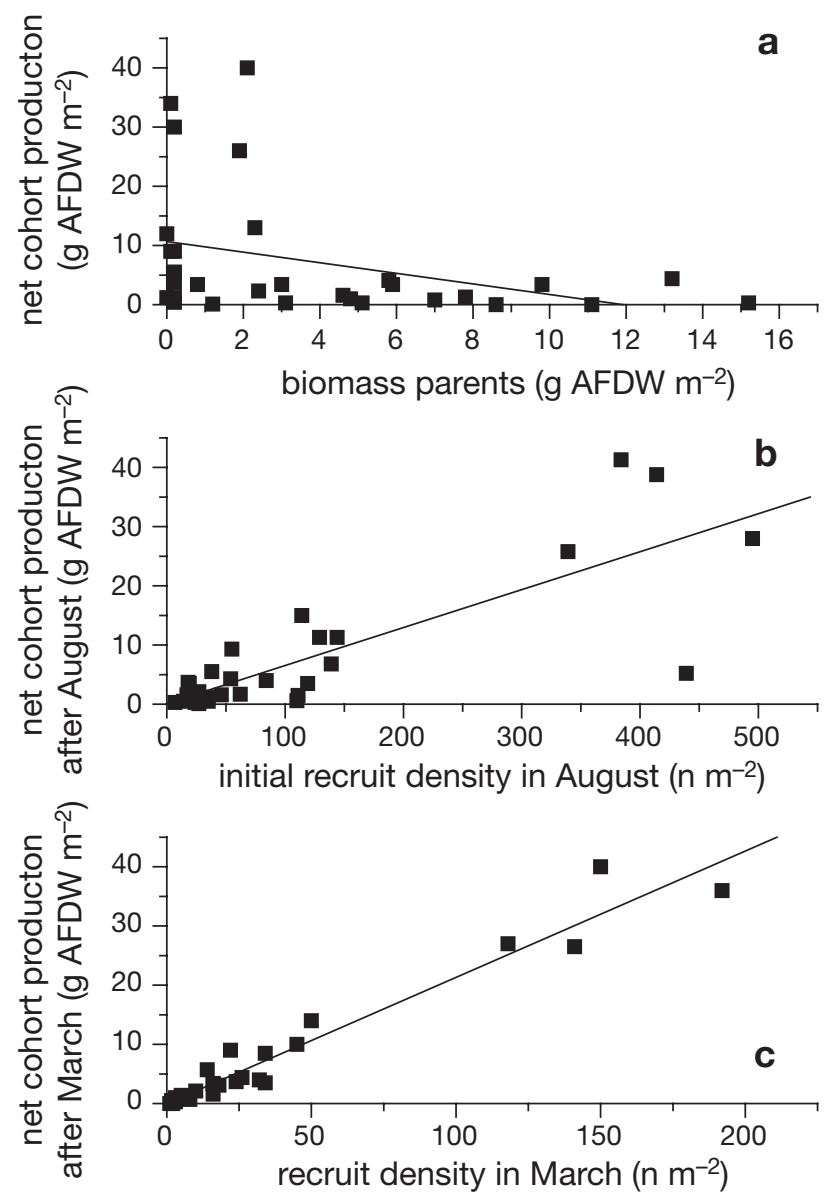

Fig. 6. Cerastoderma edule. Dependence of cohort total lifetime somatic net production of soft parts after the spat stage

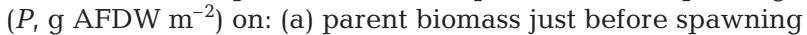
$\left(B, \mathrm{~g}\right.$ AFDW $\mathrm{m}^{-2}$ of $>1$ yr old cockles in March); (b) density of recruits $\left(D, \mathrm{n} \mathrm{m}^{-2}\right)$ in August $(\sim 3 \mathrm{mo}$ after the start of benthic life); and (c) density of recruits $\left(D, \mathrm{n} \mathrm{m}^{-2}\right)$ that survived up to March (start of growing season). The cohorts are the 30 year classes born in 1973 to 2002 (mean of 15 stations on Balgzand). Best linear fits: (a) $\mathrm{p}=10.66-0.89 B$, (b) $\mathrm{p}=0.12+$ $0.064 D$, and $(\mathrm{c}) \mathrm{p}=-0.02+0.213 \mathrm{D}$

related to cohort production (Fig. 6b: $r=0.81$ ), and cohort strength assessed at this early stage explained $>60 \%$ of the variability in cohort production.

Temporal variation in life-time production per recruit was rather erratic and did not show a clear long-term trend over the 1973 to 2002 period. Most low values could be explained by high mortality experienced during a severe winter early in life. A dependence on initial cohort strength was less clear: the strongest cohorts (born in 1975, 1979, 1987, and 1992) showed values $(0.26,0.25,0.20$, and $0.37 \mathrm{~g}$ recruit ${ }^{-1}$, respectively) that did not deviate clearly from the long-term means $\left(0.21 \mathrm{~g} \mathrm{recruit}^{-1}\right.$ for all cohorts, or $0.30 \mathrm{~g} \mathrm{recruit}^{-1}$ after the exclusion of winter-struck cohorts). 
One may wonder whether the very first estimate of cohort size, i.e. egg numbers, would also predict subsequent cohort production. Using biomass of the parent population (AFDW m ${ }^{-2}$ of adult cockles in March, just before spawning in April) as an index for numbers of eggs spawned in any year, the resulting relationship with production shown in Fig. 6a certainly does not point to a positive correlation (as did postlarval abundance some 4 mo after spawning: Fig. 6b). Rather, the relationship with egg numbers was negative: Spearman $r=-0.45, n=30, p<0.02$. From the data shown in Fig. 6a,b (or 6c), a negative stock-recruitment relationship can be deduced. Such a relationship for the Balgzand cockle population was already demonstrated by an earlier paper (Beukema \& Cadée 1999).

As a consequence of the high annual mortality rates in cockles (Beukema 1985, 1989), most of the life-time production of this species is realized within the first few years after birth. Unfortunately, our data do not allow satisfactory estimates of production realized during the first growing season at spat size. Starting from March (at an age of almost $1 \mathrm{yr}$ ), an average of $4.9 \mathrm{~g}$ $\mathrm{m}^{-2} \mathrm{yr}^{-1}$ (or $\sim 70 \%$ of the total subsequent net 'adult' production) was accomplished within $1 \mathrm{yr}$ : the year including the second growing season of their life. Subsequent years accounted for mean values of 1.3 (or $\sim 20 \%$ ), 0.7 (or $\sim 10 \%$ ), and $0.1 \mathrm{~g} \mathrm{~m}^{-2} \mathrm{yr}^{-1}$ (or $\sim 1 \%$ ), successively. A minimal estimate of the unknown firstsummer production would equal the biomass of spat assessed in August (i.e. on average $0.7 \mathrm{~g} \mathrm{~m}^{-2}$ ), but the true production (including production by spat that had died already before our sampling in August) must have been higher. Assuming that spat production was twice the August biomass, the contribution of the first-year growing season to total life-time production would amount to $\sim 20 \%$, leaving $\sim 55, \sim 15, \sim 8$, and $\sim 1 \%$ for subsequent years. Thus, the production of the year that includes the second growing season again stands out.

From the above, it is clear that the production found in any year will be particularly high if the year includes the summer 1 yr after a summer with a very successful recruitment. In such top-production years, the 1 strong cohort accounts for almost the entire production (Fig. 7a). In later years, the contribution originating from the strong cohorts rapidly diminished, both as an absolute value as well as a proportion of total annual production (Fig. 7a). Total production during each of these later years was on average also significantly lower (Wilcoxon tests with $\mathrm{n}=4+4, \mathrm{p}<0.05$ ) than during the years that included the second growing season of a strong cohort. More than 3 or 4 yr after a successful recruitment, total-production values were no longer significantly different from those of subsequent years with a negligible contribution from a strong cohort. Note the low total-production values observed $>4 \mathrm{yr}$
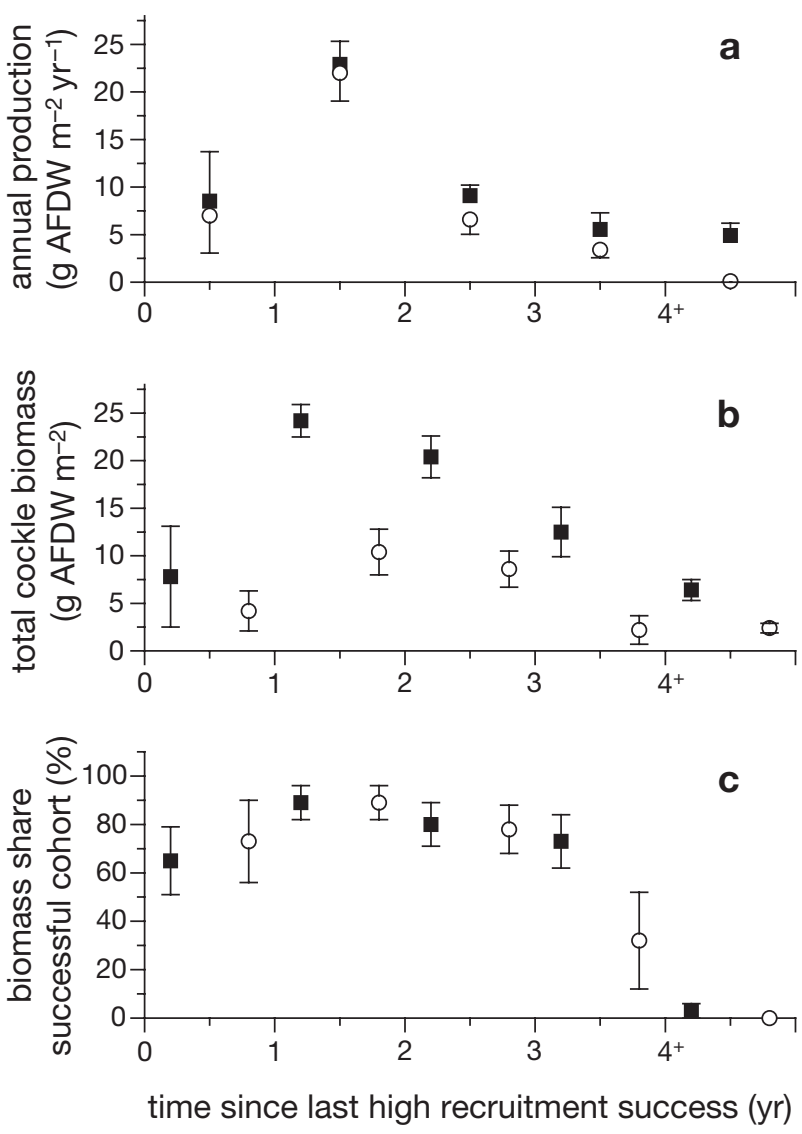

Fig. 7. Cerastoderma edule. Time course since recruitment of a strong cohort of: (a) mean annual somatic soft parts production by growth increments ( $\mathrm{g}$ AFDW $\mathrm{m}^{-2} \mathrm{yr}^{-1}$ ), for strong cohorts (O) and sum of all cohorts present (ם); (b) total (all cohorts) mean biomass ( $\mathrm{g}$ AFDW $\mathrm{m}^{-2}$ ) in August (ם) and March (O); (c) relative contribution (\%) of the strong cohorts to total cockle biomass in August (ם) and March (O). Means with 1 SE are shown for the 4 outstanding cohorts $(1975,1979$, 1987, and 1992). Thus $\mathrm{n}=4$, but $\mathrm{n}=15$ at $>4$ yr after recruitment (viz. $31-4 \times 4$ ). Note: left-most points in (a) represent production within 1st $\mathrm{yr}$ after recruitment; they were not derived from actual measurements of production during the spat stage, but were assumed to equal 2 times spat biomass in August

after a successful recruitment when the contribution of the strong cohorts had declined to near-0 values (Fig. 7a).

\section{Production and biomass}

One of the results of production by growth is change in biomass. Long-term data series of biomass values were available from biannual samples taken in August and March, i.e. $\mathrm{n}$ years $+\sim 3$ or 9 mo after the start of benthic life. In the following, we illustrate the significance of the few exceptionally strong cohorts to cockle biomass (cohorts that recruited in high numbers in 
summer and survived well in their first winter). Mean biomass values of these 4 year classes were plotted in Fig. $7 \mathrm{~b}$ as a function of the time elapsed since their successful recruitment. March values were invariably lower than preceding August values due to weight loss (Fig. 2) and relatively high mortality during the August to March periods (Beukema 1985). Maximal biomass values were observed in August around the end of the second growing season (1.3 yr after their settlement). At this time, strong cohorts accounted for nearly all of the total cockle biomass (Fig. $7 \mathrm{C}$ ). As a consequence of declining production with age (Fig. 7a) and ongoing mortality, biomass values subsequently declined (Fig. $7 b)$. The proportion of the strong cohorts among total biomass values also declined as a consequence of their lower share in production (Fig. 7a), but a strong cohort remained dominant for several years after its recruitment (Fig. $7 \mathrm{C}$ ). Final biomass values $>\sim 4$ yr after a heavy spat fall were as low as $\sim 5 \mathrm{~g} \mathrm{AFDW} \mathrm{m}^{-2}$ in late summer, and $\sim 2 \mathrm{~g} \mathrm{~m}^{-2}$ in late winter (Fig. $7 \mathrm{~b}$ ). Note that adult-cockle biomass values were invariably low (only $\sim 2 \mathrm{~g} \mathrm{AFDW} \mathrm{m}^{-2}$ or less, see Fig. 6a) in years with a successful recruitment. A highly successful recruitment was a rare event and occurred at intervals of at least $4 \mathrm{yr}$ (compare Beukema et al. 2001), when the foregoing strong year class had (nearly) disappeared (Fig. 7c) and total cockle biomass had become low (Fig. 7b).

Strong and weak cohorts differed widely in their contribution to both biomass and production, giving rise to a coincidence of years with high values of production as well as biomass (Fig. 8a). Would it then be possible to (roughly) estimate production directly from biomass assessments? The latter are much easier to obtain compared to detailed data on numbers and growth rates (of members of different age classes), which are required for a precise calculation of annual production. Annual production in each of the 29 annual (March to March) periods proved to be highly significantly correlated with total biomass gained in the first half (March to August) of these years (Fig. 8a). On average, annual cockle production was slightly higher than biomass gain during the growing season. However, despite the strong correlation $\left(r^{2}=0.86\right)$, individual true production estimates could substantially deviate from estimates of biomass gain (not infrequently up to 50 to $100 \%$, see outliers in Fig. 8a).

Biomass gains in the March to August seasons were not only highly variable among years (Fig. 8a), they also differed among age groups (Fig. 8b,c; note difference in scale). Initial biomass in March predicted subsequent biomass gain; however, this was far from precise. In young cockles $(<1 \mathrm{yr}$ old in March and still of spat size), biomass gain (in their second growing season) was on average $\sim 600 \%$ of initial biomass (Fig. $8 b$ ),
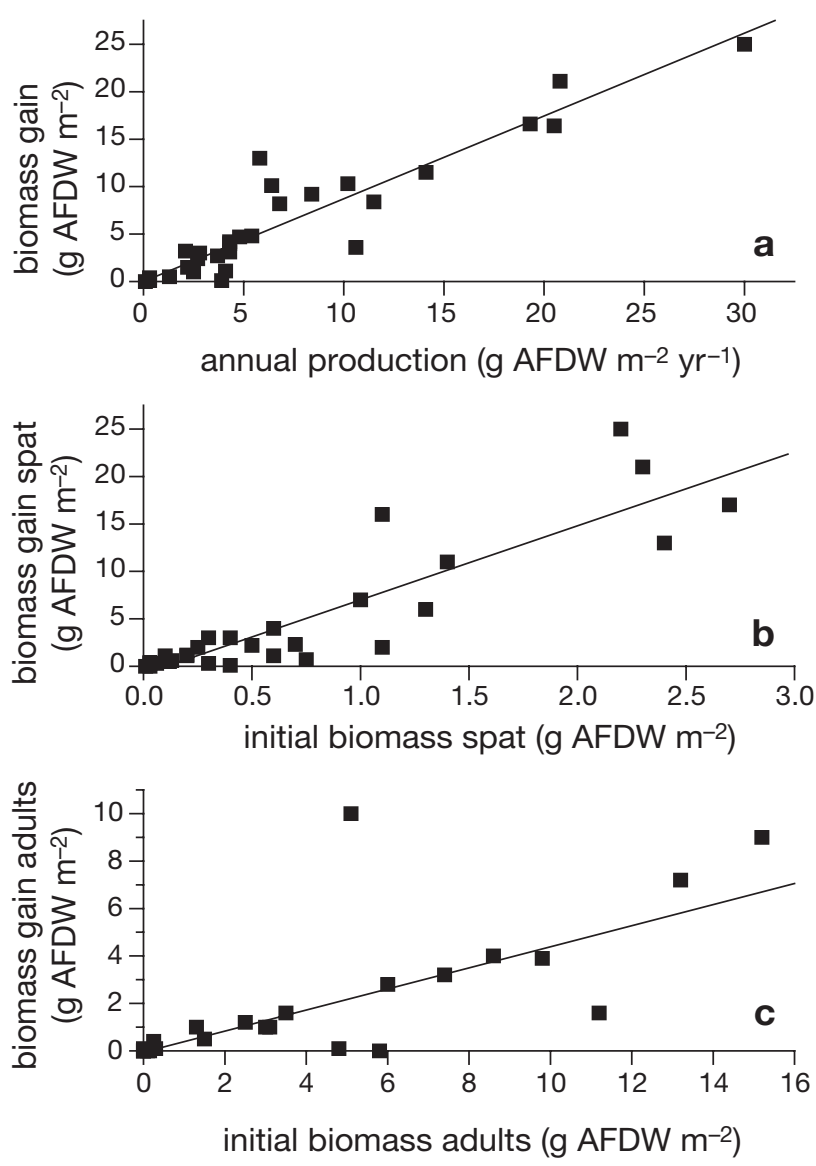

Fig. 8. Cerastoderma edule. Dependence of biomass changes $\left(\triangle B: \mathrm{g} \mathrm{AFDW} \mathrm{m}^{-2}\right.$ ) during the March to August growing seasons in each year from 1974 to 2002 on: (a) total annual $P$ during the entire year (March to March); best linear fit: $\Delta B=0.3$ $+0.85 P$ (or $\Delta B=0.87 P$ if forced through 0,$0 ; \mathrm{r}=0.93, \mathrm{n}=29$, $\mathrm{p}<0.0001)$; (b) initial $B$ of spat-sized ( $<1 \mathrm{yr}$ old) cockles at the start of the growing season and $\Delta B$ for this age group only; best fit: $\Delta B=-0.8+7.8 B$ (or $\Delta B=7.3 B ; \mathrm{r}=0.89, \mathrm{n}=29, \mathrm{p}<$ $0.0001)_{i}$ (c) initial $B$ of adult ( $>1 \mathrm{yr}$ old) cockles at the start of the growing season and $\Delta B$ for these age groups only; best fit $\Delta B=-0.06+0.44 B($ or $\Delta B=0.44 B ; \mathrm{r}=0.71, \mathrm{n}=29, \mathrm{p}<0.0001)$

whereas in older age groups (all adults, third and later growing seasons together) this was only $\sim 50 \%$ (Fig. 8c). Though absolute weight gains per individual hardly differed among these age groups (Fig. 2), relative weight growth was very different among age groups: from $<50$ to $\sim 200 \mathrm{mg}$ AFDW (or 5 to 10 times) in the youngest group (second growing season), compared to weight gains from $\sim 150$ to $\sim 400 \mathrm{mg}$ in the third growing season, or from $\sim 250$ to $\sim 500 \mathrm{mg}$ AFDW in the fourth growing season (or $\sim 2$ times) in older age groups (see Sager 1986, Figs. 2 \& 3).

As a consequence of the above differences in relative weight gain, annual $P /$ biomass $(B)$ ratios declined with age, amounting to an average of $1.6 \pm 0.2 \mathrm{yr}^{-1}$ (mean $\pm 1 \mathrm{SE}, \mathrm{n}=17$; only relatively strong cohorts 
with $B>1 \mathrm{~g} \mathrm{~m}^{-2}$ were used to avoid erratic values) for the year including the second growing season, and of $0.6 \pm 0.1$ (mean $\pm 1 \mathrm{SE}, \mathrm{n}=17$ ) for older cockles. The difference between the 2 values was highly significant ( $t$-test, $\mathrm{p}<0.0001)$.

\section{Local variation in production}

Annual mean production of soft parts of cockles varied strongly among the 15 Balgzand sampling stations, ranging from 0.1 to $20 \mathrm{~g}$ around a 15 station mean of $7 \mathrm{~g} \mathrm{AFDW} \mathrm{m}^{-2} \mathrm{yr}^{-1}$. Sites with high and low production were not randomly scattered over the area. Low production values were found both at the lowest (near the low-water level) as well as at highest (around or above MTL) intertidal levels (Fig. 9a).
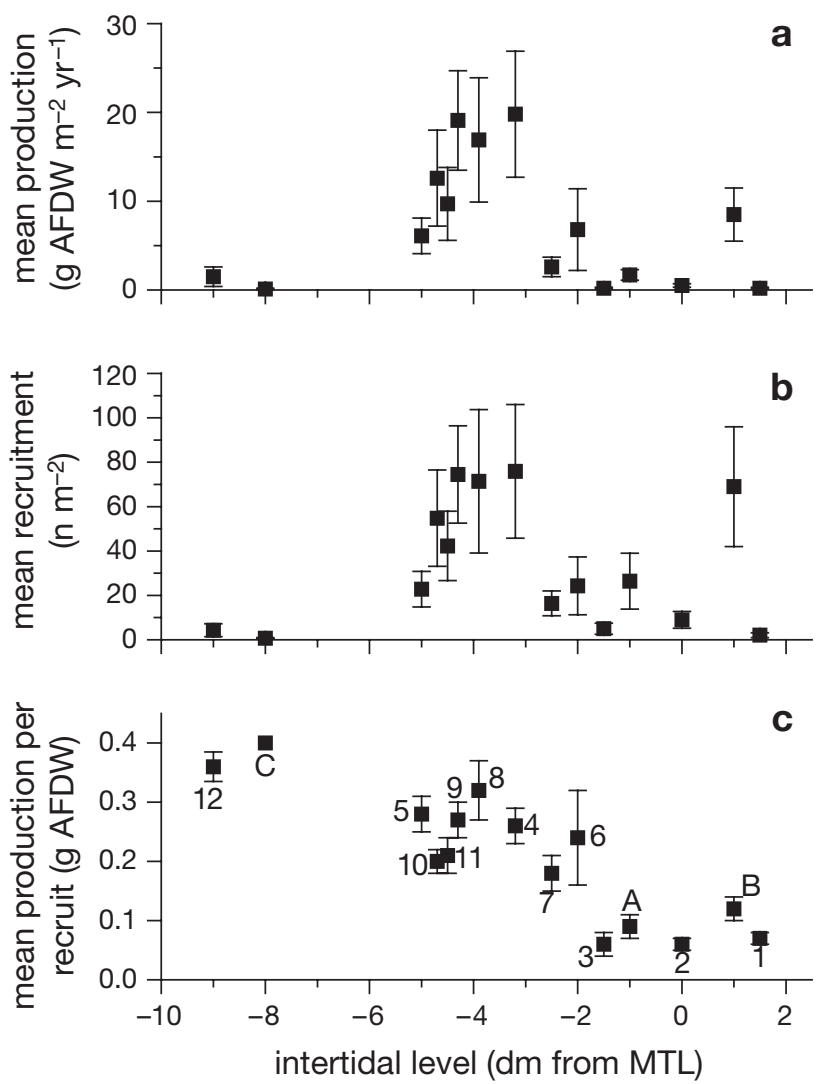

Fig. 9. Cerastoderma edule. Relationships between intertidal height of the main part of the cockle population at each of 15 sampling stations (in dm below or above mean-tide level [MTL]) and: (a) long-term mean somatic production of soft parts of cockles of $>9$ mo old ( $\mathrm{g}$ AFDW m $\mathrm{m}^{-2} \mathrm{yr}^{-1}$ ) with $1 \mathrm{SE}$ (n = 30: cohorts born from 1973 to 2002); (b) long-term mean density of recruits of these 30 cohorts as observed in March in $\mathrm{n} \mathrm{m}^{-2}$ with $1 \mathrm{SE}_{\text {; }}$ (c) mean life-time production per March recruit ( $\mathrm{g}$ AFDW ind $^{-1}$ ) with 1 SE (n between 1 and 17; at each station, cohorts with $\mathrm{n}<10$ recruits $\mathrm{m}^{-2}$ were excluded to reduce scatter); numbers: transects, capital letters: sample squares (see Fig. 1)
At both extremes, cockle recruitment (mean number of cockles of spat size $\mathrm{m}^{-2}$ in March) was generally low (Fig. 9b). Spatial variation in mean local recruit densities $D$ explained the majority of the observed spatial variation in mean production: $P=-0.64+0.23 D, \mathrm{r}^{2}=$ 0.88 ( $\mathrm{p}<0.0001$, linear regression with $\mathrm{n}=15)$. However, mean life-time production per (March) recruit also varied significantly among stations (Fig. 9c), from $\sim 0.1 \mathrm{~g} \mathrm{AFDW}$ ind..$^{-1}$ at the 5 highest stations to nearly $0.4 \mathrm{~g} \mathrm{AFDW}$ ind..$^{-1}$ at the 2 lowest stations. The negative relationship of production per recruit with intertidal level was highly significant $(r=-0.88, p<0.0001$, linear regression with $\mathrm{n}=15$ ).

In the off-shore half of Balgzand (6 stations, see Fig. 1), where intertidal levels are low and production per recruit was high, mean annual production was high in some years (up to $60 \mathrm{~g} \mathrm{AFDW} \mathrm{m}^{-2} \mathrm{yr}^{-1}$ ) and averaged $9.5 \pm 2.6 \mathrm{~g} \mathrm{AFDW} \mathrm{m}^{-2} \mathrm{yr}^{-1}$. In the near-shore half of the area, characterised by mostly higher stations and lower production per recruit, production never exceeded $15 \mathrm{~g} \mathrm{~m}^{-2} \mathrm{yr}^{-1}$ and averaged only $4.6 \pm 0.9 \mathrm{~g}$ AFDW $\mathrm{m}^{-2} \mathrm{yr}^{-1}$. In this near-shore area, no long-term trend was found in the $31 \mathrm{yr}$ data series on annual cockle production $(\mathrm{r}=0.1, \mathrm{p}=0.5)$. In the initially more important off-shore half of Balgzand, production values tended to decline over the course of the $31 \mathrm{yr}$ period, and this trend was statistically significant $(\mathrm{r}=$ $-0.42, \mathrm{p}=0.02)$, resulting in values of $<10 \mathrm{~g} \mathrm{~m}^{-2} \mathrm{yr}^{-1}$ in (nearly) all years after 1990 in this area and also over the entire Balgzand (Fig. 5a).

\section{DISCUSSION}

\section{Temporal variability in production}

Cockle production on the tidal flats of Balgzand proved to be highly variable both within a year (Fig. 3a: regular seasonal pattern) and among years during the $31 \mathrm{yr}$ period of observations (Fig. 5a: heavy irregular fluctuations).

The short-term month to month variation was mainly due to the annual growth pattern with a rather short growing season in spring and summer followed by a longer autumn-winter period that was characterized by consistent weight losses (Fig. 2). These losses started earlier in summer/autumn and were proportionally larger in old rather than in young cockles.

Seasonal weight loss appears to be characteristic of cockles and also other bivalves living at temperate latitudes (Zwarts 1991, Honkoop \& Beukema 1997). Generally, 2 environmental factors appear to enhance rates of weight loss in bivalves in autumn and winter: high water temperature, and low food supply (Honkoop \& Beukema 1997). In periods of low food supply (as is the 
case in the Wadden Sea in autumn and winter, see Beukema \& Cadée 1996), high water temperatures cause high metabolic costs, and these energy demands are met by reserve material and thus lead to the observed substantial weight losses in all winters, but especially in mild winters. Food supply will be another factor governing rates of weight loss. During an exceptional winter (1990/1991) with abnormally high phytoplankton concentrations in Wadden Sea water, several bivalves (including cockles) showed unusually minimal weight losses (Beukema \& Cadée 1996). The high food supply in this particular winter was caused by exceptionally low cockle and mussel stocks as a consequence of heavy fishing of already depleted stocks. After 1990, mussel Mytilus edulis stocks remained at a very low level in the westernmost part of the Wadden Sea, and food competition will have remained relaxed. At the same time, winter temperatures tended to increase. The net effect of these contrasting influences on cockle weight losses was a negligible and non-significant difference in relative winter production loss (26 and 22\% of preceding growing-season production in the first and second half of the observation period, respectively).

Consistent negative contributions to production during part of the year are not evident in any published studies on cockle production, e.g. because seasonal growth was primarily studied by length measurements (and shells do not lose length in winter), or because weight changes were derived from 1 or a few determinations of the length-weight relationships (e.g. Warwick \& Price 1975, Sauriau \& Kang 2000). Results of such incomplete studies are almost certainly biased. Some examples of full annual curves of annual weights that can be adequately used for production estimates are those by Wolff \& De Wolf (1977), Ivell (1981), and Iglesias \& Navarro (1991).

For the entire Balgzand population, net annual production values were positive, though sometimes close to 0 (see Fig. 5a). These low net values were due to low cockle densities rather than poor growing conditions. Thus, averaged over the total population, weight gains in spring/summer invariably exceeded subsequent losses in autumn/winter, resulting in positive net annual production values in all years. Only occasionally at some stations in some years could losses exceed preceding gains, but this occurred exclusively in the oldest age groups. Such negative annual production values in old cockles also occurred in a Spanish cockle population, as can be inferred from Fig. 2 of Iglesias \& Navarro (1991). Negative annual production estimates obtained by the weight-increment method appear to be rare for entire populations, but are certainly possible, viz. if mean individual weights have declined after $1 \mathrm{yr}$ in most members of a population, as described in part of a mussel population by Cusson \& Bourget (2005).
Substantial seasonal weight losses (of up to 60\% of preceding seasonal weight gain in older age groups) complicate assessments of annual production of soft parts. Though unbiased estimates of annual production can be obtained by annual sampling if executed in the correct month (either June or December, see Fig. 4), such limited effort could easily result in biased estimates if not executed at the right time of the year (Fig. 3b). The biannual sampling we prefer can yield proper and meaningful values for both seasonal as well as annual net production if executed at the correct time of the year, i.e. at the times the individual weights are either minimal or maximal. In this case, negative production in autumn/winter can be subtracted from the foregoing positive spring/summer production to obtain an estimate for net annual production. Provided that rates of growth and mortality are more or less constant within the 2 half-year periods, the present estimates based on samples taken biannually at the right time will be close to estimates based on more frequent sampling. In practice, growth rates were relatively rapid early in the growing season (Fig. 2). Mortality rates within years were not studied in such detail because the monthly samples were generally too small to separate trends in monthly rates from the data 'noise'. It is known that cockle mortality is higher in winter than in summer (Van der Meer et al. 2001a; see also Fig. 4), can be extremely high in severe winters (Beukema 1985), and takes place mainly within a relatively short period at the end of the weight-loss season. Thus, some errors will remain with the present method, but we believe that our long-term values were essentially unbiased, as indeed they proved to be at the 2 frequently sampled stations. The estimate of a mean (25 yr: 1974 to 1998, inclusive) value for cockle production at 11 of our Balgzand sites of $11.2 \mathrm{~g} \mathrm{~m}^{-2} \mathrm{yr}^{-1}$ as determined by Van der Meer et al. (2001a) using a different method (estimating production as an elimination from annual mortality rates and biomass) was similar to our estimate of $11.4 \mathrm{~g} \mathrm{~m}^{-2} \mathrm{yr}^{-1}$ for the same years and sites. To derive a comparable value from our estimates, we had to add the mean spat biomass in August $\left(1.3 \mathrm{~g} \mathrm{~m}^{-2}\right)$ to the mean net August to August production (10.1 $\left.\mathrm{g} \mathrm{m}^{-2} \mathrm{yr}^{-1}\right)$, because the amounts of subsequently eliminated spat were included in the estimate of Van der Meer et al. (2001a). Of course, the 2 estimates should be similar, because in the long term the amounts produced are bound to equal the amounts eliminated (unless biomass values were grossly different at the start and end of the measurement period). The similarity of the 2 estimates means that both methods (growth summation and elimination summation) were adequate and probably free of substantial errors. 
The strong fluctuations in the long-term data series on annual cockle production (Fig. 5a) raises the question: how long should a study last to yield a representative mean annual value? From the start of the present Balgzand study, a minimum of $\sim 10 \mathrm{yr}$ of observation were needed to stabilize the (cumulative) estimate of mean annual production (Fig. 5b). If a study is aimed at obtaining an estimate within a certain limit (e.g. 10\%) from the long-term mean, even more years of observation might be needed in areas with highly variable production. At Balgzand, no less than 20 annual estimates would be necessary to obtain an average value that has a $>50 \%$ chance to deviate $<10 \%$ from the long-term mean (Fig. 5c). However, obtaining a precise and representative long-term average from highly variable annual estimates is unrealistic if the annual data show a long-term trend, as observed in the offshore half of the area that reflected the declining trend of annual cockle recruitment in this part of Balgzand (Beukema \& Dekker 2005).

Studies of a considerable length $(>10 \mathrm{yr}$ ) on production of zoobenthos appear to be rare. To date, there appears to be no previous long-term studies on cockles (Table 1). The $>10$ studies (in other areas than Balgzand) listed in Table 1 were all $<6$ yr in duration, and in general spanned only 1 to 3 yr. Therefore, these studies were probably not able to obtain representative values of cockle production in any area. Some published values are so high that they must refer strictly to local areas (cockle beds) and/or to temporary conditions (a short period after a highly successful recruitment). Total tidal-flat-community estimates of

Table 1. Cerastoderma edule. Published estimates of mean annual somatic soft-parts production $\left(P\right.$ or $\left.E: \mathrm{g} \mathrm{AFDW} \mathrm{m}^{-2} \mathrm{yr}^{-1}\right)$ with estimates of annual mean biomass $\left(B: \mathrm{g} \mathrm{AFDW} \mathrm{m}^{-2}\right.$ ) and $P / B$ or $E / B$ (both $\mathrm{yr}^{-1}$ ) in various regions (arranged from $\mathrm{N}$ to $\mathrm{S}$ ), as based on numbers of years of observation (yr) and sampling stations (stn). Method: estimates were made either as $P$ (sums of growth increments), $E$ (elimination), or $O$ (otherwise). Age given in $\mathrm{yr}$; ad: adults

\begin{tabular}{|c|c|c|c|c|c|c|c|c|}
\hline Area & Method & Age & & f & $P(E)$ & $B$ & $P(E) / B$ & Source \\
\hline \multirow{10}{*}{ Sweden } & $P$ & $\mathrm{ad}$ & 3 & 1 & 18 & 116 & 0.2 & \multirow{4}{*}{ Evans (1977) } \\
\hline & $P$ & $\mathrm{ad}+1$ & 3 & 1 & 3 & 18 & 0.2 & \\
\hline & $E$ & ad & 3 & 1 & 188 & 116 & 1.6 & \\
\hline & $E$ & $\mathrm{ad}+1$ & 3 & 1 & 27 & 18 & 1.5 & \\
\hline & $P$ & 0 & 5 & 3 & 11 & 2.5 & 4.4 & \multirow[t]{2}{*}{ Moller \& Rosenberg (1983) } \\
\hline & $E$ & 0 & 5 & 3 & 9 & 2.5 & 3.5 & \\
\hline & $P$ & 0 & 1 & 2 & 1.4 & & 4.6 & \multirow[t]{4}{*}{ Loo \& Rosenberg (1989) } \\
\hline & $E$ & 0 & 1 & 2 & 1.2 & & & \\
\hline & $P$ & ad & 1 & 2 & 1.5 & & 0.7 & \\
\hline & $E$ & $\mathrm{ad}$ & 1 & 2 & 1.5 & & & \\
\hline \multirow[t]{2}{*}{ Denmark } & $O$ & $\sim 1$ & 1 & 1 & 130 & & & Ivell (1981) \\
\hline & $P$ & $0-3$ & 3 & 3 & 44 & & & Jensen (1993) \\
\hline Germany & $P$ & $0-3$ & 2 & 4 & 49 & 95 & 0.5 & Ramon (2003) \\
\hline \multirow[t]{6}{*}{ Netherlands } & $P$ & 1 & 30 & 15 & 4.9 & 3.3 & 1.5 & \multirow[t]{4}{*}{ Present paper } \\
\hline & & 2 & 30 & 15 & 1.3 & 2.3 & 0.6 & \\
\hline & & $3+$ & 30 & 15 & 0.7 & 1.5 & 0.5 & \\
\hline & & $1+$ & 30 & 15 & 6.8 & 7.1 & 1.0 & \\
\hline & $E$ & $0+$ & 25 & 12 & 11.2 & & & Van der Meer et al. (2001a) \\
\hline & $P$ & $0-2$ & 1 & 6 & 19 & 36 & 1.9 & Wolff \& De Wolf (1977) \\
\hline \multirow[t]{2}{*}{ England } & $P$ & & 1 & 1 & 0.2 & 1 & 0.2 & Warwick \& Price (1975) \\
\hline & $P$ & $1-7$ & 1 & 3 & 49 & 34 & 1.4 & Hibbert (1976) \\
\hline \multirow[t]{2}{*}{ France } & $P$ & $0-5$ & 1 & 1 & 32 & 14 & 2.3 & \multirow[t]{2}{*}{ Sauriau \& Kang (2000) } \\
\hline & $E$ & $0-5$ & 1 & 1 & 35 & 14 & 2.4 & \\
\hline Portugal & $O$ & & 3 & 3 & 2 & 2 & 1.1 & Dolbeth et al. (2003) \\
\hline
\end{tabular}


zoobenthic production amount to values of usually $<100 \mathrm{~g} \mathrm{AFDW} \mathrm{m}^{-2} \mathrm{yr}^{-1}$. Dolbeth et al. (2003) reported a range of 7 to 185 (mostly $\sim 20$ to $\sim 70$ ), with an average of $53 \mathrm{~g} \mathrm{~m}^{-2} \mathrm{yr}^{-1}$ from 7 studies on 18 areas. McLusky et al. (1995) summarized 7 other studies in 8 areas, and reported a range of 13 to 53 with an average of $28 \mathrm{~g} \mathrm{~m}^{-2}$ $\mathrm{yr}^{-1}$. If cockles account for a substantial contribution to total zoobenthic secondary production, their share would probably be somewhere between 10 and $20 \%$. Therefore, we would expect representative and sustainable values of around 10 (and maximally 20 ) $\mathrm{g} \mathrm{m}^{-2}$ $\mathrm{yr}^{-1}$ for cockle production. Our long-term multi-station mean Balgzand estimate of $\sim 7 \mathrm{~g}$ is within a plausible 10 to $20 \%$ of total benthic secondary production that is to be expected in productive tidal-flat communities.

The above estimate of $\sim 7 \mathrm{~g}$ AFDW m $\mathrm{m}^{-2} \mathrm{yr}^{-1}$ does not fully account for total annual production by cockles. Neither the production in their first year of life (estimated at $\sim 1.5 \mathrm{~g} \mathrm{~m}^{-2} \mathrm{yr}^{-1}$, if it equals $\sim 2$ times the August biomass of spat), nor the gamete production were included in the estimate, and neither was the organic contents of the shells. Iglesias \& Navarro (1991) estimated gamete production over 2 yr in a Spanish cockle population and found values of $\sim 10$ and $\sim 20 \%$ of the total production that was accomplished in the first half of the year (the 2 values are for a year with low and high growth rates, respectively). If we assume that such proportions were also applicable for Balgzand, this would result in a mean gamete production of $\sim 1$ to $\sim 2 \mathrm{~g} \mathrm{AFDW} \mathrm{m}^{-2} \mathrm{yr}^{-1}$ that should be added to our somatic-production estimates. Mean cockle shell production on Balgzand amounts to $125 \mathrm{~g} \mathrm{~m}^{-2} \mathrm{yr}^{-1}$ (Beukema \& Cadée 1999), and these shells may contain $\sim 1 \%$ of organic matter, adding another $\sim 1 \mathrm{~g} \mathrm{~m}^{-2}$ $\mathrm{yr}^{-1}$ to the annual cockle production. Thus, total annual cockle production might amount to a long-term average of slightly over $10 \mathrm{~g}$ organic material $\mathrm{m}^{-2} \mathrm{yr}^{-1}$.

\section{Spatial variability in production}

The estimates of mean cockle production among the 15 Balgzand stations differed widely (Fig. 9a), as is to be expected in a heterogeneous area. Particularly low values were observed at the extremes of the intertidal range. These border areas (either close to the shore or far off shore) were not only characterized by extreme levels, but also by relatively extreme environmental conditions: most of the high stations were located in sheltered areas close to the shore where the sediment is muddier than at other stations, whereas the 2 low stations were in exposed areas far off-shore, where tidal currents and wave action are relatively strong and the silt content of the sediment is lower than at other stations. In such extreme areas, zoobenthos abundance appears to be limited primarily by adverse abiotic conditions (Beukema \& Cadée 1997). Accordingly, cockle recruitment was much lower in these areas than in the central part of Balgzand at intermediate intertidal levels (Fig. 9b). These differences in initial numerical abundance explained most of the place to place differences in cockle production (compare Fig. 9a,b).

Lifetime production per recruit also differed among the sampling stations and did so in a consistent way: the lower the intertidal level was at a station, the higher was the production per recruit (Fig. 9c). Two processes contributed to the observed relatively low production per recruit at high intertidal levels. At high as compared to low intertidal levels, (1) cockle growth rates are lower (Kreger 1940, Jensen 1992, De Montaudouin 1996, Beukema \& Dekker unpubl. data,) and (2) over-winter survival rates are lower (Beukema 1985).

The observed high spatial variability in cockle production calls into question whether the 15-station mean is representative for the entire Balgzand area. We believe that it is, because the 15 stations were scattered (almost) randomly over the area and covered all intertidal levels and sediment types, roughly in accordance with their surface area. This statement is supported by a comparison with independent results of a 6 yr sampling program executed by the Netherlands Institute for Fisheries Research (RIVO), which included 70 sampling sites on Balgzand. The RIVO Balgzand mean estimates for both numerical densities and biomass of cockles proved to be close to our 15-station means, as shown in Fig. 4 of Beukema \& Cadée (1999). Thus, both data sets will give a fair representation of the actual sizes of the cockle stocks on Balgzand.

\section{Causes underlying production variability}

Mean recruit density at an age of almost 1 yr predicted further lifetime cohort production on Balgzand (Fig. 6c), and explained nearly all of the variance in cohort production. A close dependence of life-time production on initial cohort density (and thus on recruitment success in a particular year) was also observed in the bivalve Macoma balthica (Van der Meer et al. 2001b). For other bivalves on Balgzand (such as Mytilus edulis and Mya arenaria), our longterm monitoring data also point to recruitment variability as the primary factor governing productivity variation (unpubl. data). Unfortunately, published estimates on production in other species and in other areas were derived from short study periods only and are therefore inadequate to draw on in order to question which factors (recruitment, survival, growth) primarily 
affect productivity. The close relationship shown in Fig. 6c for cockles on Balgzand leaves little space for a significant influence of other factors such as annual variation in survival and growth rates. We found some influence of high mortality in severe winters if this occurred early in the life of a cohort (explaining most of the differences between Fig. 6b,c). Though growth rates in cockles are generally reported to be lower at high rather than low numerical densities (Kristensen 1957, Peterson \& Black 1987, Jensen 1992, 1993, De Montaudouin 1996), our observed values of mean production per recruit did not clearly differ between large and small cohorts, resulting in a straight relationship between density and production as shown in Fig. 6c. In practice, growth reduction in cockles appears to become substantial only at very high numerical densities (several hundred $\mathrm{m}^{-2}$ ) occurring over vast areas. Note that 15-station mean recruit densities at the start of the (second) growing season never exceeded $200 \mathrm{~m}^{-2}$ on Balgzand (Fig. 6c). Local densities in cockle beds on Balgzand were sometimes higher (though never exceeding $\sim 1000 \mathrm{~m}^{-2}$ ), but it should be kept in mind that cockles and other filter feeders in a tidal environment do not exclusively depend on locally produced food but mostly consume algae that is produced over vast surrounding areas and supplied by tidal currents.

Our conclusion that the main determinant of temporal variability in cockle production is variability in recruitment holds true also for local (station to station) variation in cockle production: compare the similar patterns in Fig. 9a,b.

In the Wadden Sea, cockle recruitment is highly variable and appears to be primarily governed by factors related to the character of the foregoing winter (Strasser et al. 2003, Beukema \& Dekker 2005). In particular, the abundance of epibenthic predators (shrimps) on the tidal flats at the time (May, June) of arrival of early benthic stages (postlarvae) of cockles may be decisive (Beukema \& Dekker 2005), and at this time shrimps are more abundant after mild rather than cold winters (Beukema 1992). Though cold winters before spat fall appear to promote subsequent recruitment success, a cold winter after recruitment seriously reduces cohort strength (Beukema 1985). Therefore, in order to precisely predict life-time cohort production, it is only sensible to assess cohort strength after the first winter of their life (Fig. 6c).

Continuation of the present climate change, with a declining incidence of cold winters, would be unfavourable for the recruitment of strong cockle cohorts. This is particularly so at lower tidal flats where shrimps are usually abundant at the time postlarvae of cockles (and other bivalves) start their benthic life (Beukema \& Dekker 2005). Thus, future prospects for high production and biomass of cockles in the Wadden Sea may be poor.

\section{Consequences for consumers of cockles}

Some birds wintering in the Wadden Sea (oystercatchers, eiders) are characterized by a specialized diet dominated by large bivalves (such as cockles and mussels). Each winter, these birds require a sufficiently high abundance of these prey. The amount of cockles that is required to satisfy food requirements of 260 000 wintering oystercatchers (i.e. population estimate in the 1980s, before food shortage caused a decline in population size to the present 180000 ) has been estimated by Rappoldt et al. (2003); their results are summarized in Fig. 75 of Ens et al. (2004). In the absence of mussel beds (the main alternative food source for oystercatchers and eiders), the 'ecological' (see Goss-Custard et al. 2004) needs of these birds in the Dutch Wadden Sea demand a late-summer stock of about $52 \times 10^{6} \mathrm{~kg}$ wet weight of cockle flesh. In the presence of $40 \mathrm{~km}^{2}$ of mussel beds, this minimal stock requirement could be lower, $\sim 25 \times 10^{6} \mathrm{~kg}$. These amounts are equivalent to $\sim 8$ and $\sim 4 \mathrm{~g} \mathrm{AFDW} \mathrm{m}^{-2}$, respectively (area of tidal flats $1250 \mathrm{~km}^{2}$, conversion factor of wet weight to AFDW: 0.2).

Data on actual amounts of soft parts of cockles present in late summer on tidal flats (Fig. 10) are available from 1973 for the $50 \mathrm{~km}^{2}$ of Balgzand and, since 1990, are also for the entire Dutch Wadden Sea. Starting in

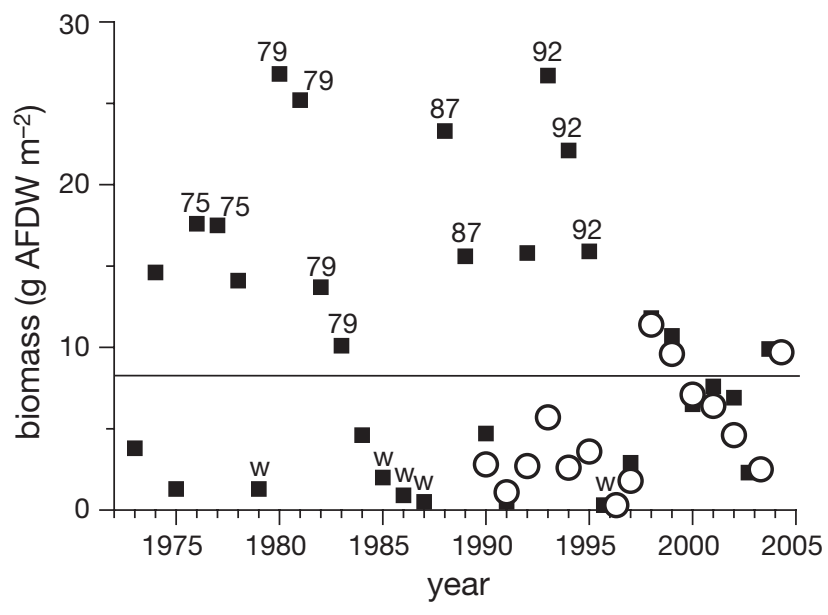

Fig. 10. Cerastoderma edule. Mean adult-cockle biomass (g AFDW $\mathrm{m}^{-2}$ ) in successive years on tidal flats of 2 areas: ( $\square$ ) Balgzand, August values from 1973 to 2004; (O) entire Dutch Wadden Sea, extrapolated to 1 September from 1990 to 2004 period (P. Kamermans pers. comm.). Horizontal line at biomass value of $8 \mathrm{~g} \mathrm{~m}^{-2}$ indicates food requirements of oystercatchers. w: summers that followed a severe winter; year number: year of birth of strong cohorts that dominated contributions to biomass. Note: Balgzand and total Wadden Sea values corresponded closely from 1996 onwards, but differed markedly between 1992 and 1995 when Balgzand values were dominated by strong localised cohorts born in 1991 and 1992 
1990, cockles were sampled at $>1000$ stations each year in spring (Van Stralen 1990), and data on total weights were converted to AFDW values of soft parts to be expected on the tidal flats in September (P. Kamermans pers. comm.), following methods described in Kamermans et al. (2003). Total weights (which include shells and seawater within the shell doublets) were converted to AFDW by multiplication by a conversion factor of 0.0332 . Among the 15 annual values for the entire Dutch Wadden Sea in the 1990 to 2004 period, only $20 \%$ exceeded the level of $8 \mathrm{~g}$ AFDW $\mathrm{m}^{-2}$ (Fig. 10). For the limited area of Balgzand, the situation in this period was more favourable for oystercatchers: almost half ( 7 out of 15 ) of the values were above the requirement level of these birds, particularly those of the 4 years 1992 to 1995 (Fig. 10; compare also Fig. 2.3 of Kamermans et al. 2003). The difference between Balgzand and the entire Dutch Wadden Sea was due to the cohorts born in 1991 and 1992 that happened to be strong on Balgzand but not in most other parts of the Wadden Sea. In the remaining 11 years, the biomass values for Balgzand and the entire Dutch Wadden Sea were very similar (mean biomass Wadden Sea $=0.91 \times$ mean biomass Balgzand, $\mathrm{r}=0.97, \mathrm{n}=11$, $\mathrm{p}<0.0001)$. In the years before 1990, annual data were limited to Balgzand and in most years (10 out of 17)

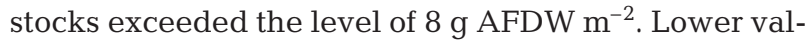
ues were mostly caused by severe winters (indicated by ' $w$ ' in Fig. 10), whereas nearly all high values were due to the contributions of a few strong cohorts (marked in Fig. 10 by their year of birth). Nearly all high biomass values could be attributed to the 4 marked strong cohorts, and these high values continued for a limited number of years only (compare also Fig. 7b). Thus, high cockle stocks are guaranteed only if a strong cohort arises every 4 or 5 yr (as was generally the case in the first 2 decades of the period of observation). Note that the exceptionally strong cohorts of 1979 and 1987 originated in the summer immediately following a severe winter. The total absence of cold winters after 1997 may have contributed to the absence of notably strong cohorts in the last decade.

The estimate of $8 \mathrm{~g}$ AFDW $\mathrm{m}^{-2}$ of cockle flesh required to fully meet food demands of wintering oystercatchers roughly equals the long-term median value of cockle biomass on Balgzand, and is thus quite high. At present, it is not warranted to lower this $8 \mathrm{~g}$ AFDW $\mathrm{m}^{-2}$ threshold, because alternative food is scarce. So far, mussel banks have recovered very little on the tidal flats of the western half of the Dutch Wadden Sea after heavy fishing around 1990 (Dankers et al. 2003). Other bivalves of a suitable size to serve as food for oystercatchers are also scarce in this area. At present, the stock of adult Macoma balthica has declined to
$<0.5 \mathrm{~g} \mathrm{AFDW} \mathrm{m}^{-2}$, and that of juvenile Mya arenaria to $\sim 1.5 \mathrm{~g} \mathrm{~m}^{-2}$ (NIOZ Balgzand monitoring program unpubl. data). Therefore, the recent decision of the Dutch government to close the mechanical fishery for cockles was the only sensible means of ending conflict between nature conservation and fishery. In fact, such a decision should have been made in 1990. In view of the generally low recruitment success of cockles over the last 15 yr (Beukema \& Dekker 2005) and the poor prospects for the development of future strong cohorts, any cockle fishing in the Wadden Sea may be considered harmful to wintering birds.

Acknowledgements. This study is part of a long-term monitoring program on macrozoobenthos in the Wadden Sea executed by NIOZ and financially supported by the Dutch National Institute for Coastal and Marine Management (RWS/RIKZ). We thank our colleagues P. Kamermans (RIVO) and J. van der Meer (NIOZ) for their comments on earlier versions of this paper.

\section{LITERATURE CITED}

Beukema JJ (1976) Biomass and species richness of the macrobenthic animals living on the tidal flats of the Dutch Wadden Sea. Neth J Sea Res 10:236-261

Beukema JJ (1982) Annual variation in reproductive success and biomass of the major macrozoobenthic species living in a tidal flat area of the Wadden Sea. Neth J Sea Res 16: $37-45$

Beukema JJ (1985) Zoobenthos survival during severe winters on high and low tidal flats in the Dutch Wadden Sea. In: Gray JS, Christiansen ME (eds) Marine biology of polar regions and effects of stress on marine organisms. John Wiley, Chichester, p 351-361

Beukema JJ (1989) Bias in estimates of maximum life span, with an example of the edible cockle, Cerastoderma edule. Neth J Zool 39:79-85

Beukema JJ (1992) Dynamics of juvenile shrimp Crangon crangon in a tidal-flat nursery of the Wadden Sea after mild and cold winters. Mar Ecol Prog Ser 83:157-165

Beukema JJ, Cadée GC (1996) Consequences of the sudden removal of nearly all mussels and cockles from the Dutch Wadden Sea. Mar Ecol 17:279-289

Beukema JJ, Cadée GC (1997) Local differences in macrozoobenthic response to enhanced food supply caused by mild eutrophication in a Wadden Sea area: food is only locally a limiting factor. Limnol Oceanogr 42:1424-1435

Beukema JJ, Cadée GC (1999) An estimate of the sustainable rate of shell extraction from the Dutch Wadden Sea. J Appl Ecol 36:49-58

Beukema JJ, Dekker R (2005) Decline of recruitment success in cockles and other bivalves in the Wadden Sea: possible role of climate change, predation on postlarvae and fisheries. Mar Ecol Prog Ser 287:149-167

Beukema JJ, Essink K, Michaelis H, Zwarts L (1993) Year-toyear variability in the biomass of macrozoobenthic animals on tidal flats of the Wadden Sea: How predictable is this food source for birds? Neth J Sea Res 31:319-330

Beukema JJ, Dekker R, Essink K, Michaelis H (2001) Synchronized reproductive success of the main bivalve species in the Wadden Sea: causes and consequences. Mar Ecol Prog Ser 211:143-153

Camphuysen CJ, Ens BJ, Heg D, Hulscher JB, Van der Meer 
J, Smit CJ (1996) Oystercatcher Haematopus ostralegus winter mortality in the Netherlands: the effect of severe weather and food supply. Ardea 84A:469-492

Camphuysen CJ, Berrevoets CM, Cremers HJWM, Dekinga A and 8 others (2002) Mass mortality of common eiders (Somateria mollissima) in the Dutch Wadden Sea, winter 1999/2000: starvation in a commercially exploited wetland of international importance. Biol Conserv 106:303-317

Crisp DJ (1984) Energy flow measurements. In: Holme NA, McIntyre AD (eds) Methods for the study of marine benthos. Blackwell, Oxford, p 284-372

Cusson M, Bourget E (2005) Small-scale variations in mussel (Mytilus spp.) dynamics and local production. J Sea Res 53:255-268

Dankers NMJA, Meijboom A, Cremer JSM, Dijkman EM, Hermes Y, te Marvelde L (2003) Historische ontwikkeling van droogvallende mosselbanken in de Nederlandse Waddenzee. Alterra-rapport 876, Alterra, Wageningen

De Montaudouin X (1996) Factors involved in growth plasticity of cockles Cerastoderma edule (L.), identified by field survey and transplant experiments. J Sea Res 36:251-256

Dolbeth M, Pardal MA, Lillebo AI, Azeiteiro U, Marques JC (2003) Short- and long-term effects of eutrophication on the secondary production of an intertidal macrobenthic community. Mar Biol 143:1229-1238

Ens BJ, Smaal AC, De Vlas J (2004) The effects of shellfish fishery on the ecosystems of the Dutch Wadden Sea and Oosterschelde. Alterra Report 1011 (RIVO-rapport C056/04, RIKZ-rapport RKZ/2004.031), Alterra, Wageningen

Evans S (1977) Growth, production, and biomass release of a non-stable population of Cardium edule L. (Bivalvia). Zoon 5:133-141

Goss-Custard JD, Stillman RA, West AD, Caldow RWG, Triplet P, Le V dit Durell SEA, McGrorty S (2004) When enough is not enough: shorebirds and shellfishing. Proc R Soc Lond B 271:233-237

Hibbert CJ (1976) Biomass and production of a bivalve community on an intertidal mudflat. J Exp Mar Biol Ecol 25: 249-261

Honkoop PJC, Beukema JJ (1997) Loss of body mass in winter in three intertidal bivalve species: an experimental and observational study of the interacting effects between water temperature, feeding time and feeding behaviour. J Exp Mar Biol Ecol 212:277-297

Iglesias JIP, Navarro E (1991) Energetics of growth and reproduction in cockles (Cerastoderma edule): seasonal and age-dependent variations. Mar Biol 111:359-368

Ivell R (1981) A quantitative study of a CerastodermaNephtys community in the Limfjord, Denmark, with special reference to production of Cerastoderma edule. J Molluscan Stud 47:147-170

Jensen KT (1992) Dynamics and growth of the cockle, Cerastoderma edule, on an intertidal mud-flat in the Danish Wadden Sea: effects of submersion time and density. Neth J Sea Res 28:335-345

Jensen KT (1993) Density-dependent growth in cockles (Cerastoderma edule): evidence from interannual comparisons. J Mar Biol Assoc UK 73:333-342

Editorial responsibility: Otto Kinne (Editor-in-Chief), Oldendorf/Luhe, Germany
Kamermans P, Kestelo J, Baars D (2003) Evaluatie van de geschatte omvang en ligging van kokkelbestanden in de Waddenzee, Ooster- en Westerschelde. RIVO Rapport C054/03, RIVO, Yerseke

Kreger D (1940) On the ecology of Cardium edule. Arch Neerl Zool 4:157-200

Kristensen I (1957) Differences in density and growth in a cockle population in the Dutch Wadden Sea. Arch Neerl Zool 12:351-453

Loo LO, Rosenberg R (1989) Bivalve suspension-feeding dynamics and benthic-pelagic coupling in an eutrophicated marine bay. J Exp Mar Biol Ecol 130:253-276

McLusky DS, Briche N, Desprez M, Duhamel S, Rybarczyk H, Elkaim B (1995) The benthic production of the Baie de Somme, France. In: Eleftheriou A (ed) Proc 28th Eur Mar Biol Symp. Olsen \& Olsen, Fredensborg, p 225-231

Möller P, Rosenberg R (1983) Recruitment, abundance and production of Mya arenaria and Cardium edule in marine shallow waters, western Sweden. Ophelia 22:33-55

Peterson CH, Black R (1987) Resource depletion by active suspension feeders on tidal flats: influence of local density and tidal elevation. Limnol Oceanogr 32:143-166

Ramon M (2003) Population dynamics and secondary production of the cockle Cerastoderma edule (L.) in a backbarrier tidal flat of the Wadden Sea. Sci Mar 67:429-443

Rappoldt C, Ens BJ, Dijkman E, Bult T (2003) Scholeksters en hun voedsel in de Waddenzee. Alterra Rapport 882, Alterra, Wageningen

Sager G (1986) Wachstumsspezifische Approximationen für die Herzmuschel Cerastoderma edule L. in der Waddensee nach Daten von Beukema (1975-78). Beitr Meeresk 55:55-66

Sauriau PG, Kang CK (2000) Stable isotope evidence of benthic microalgae-based growth and secondary production in the suspension feeder Cerastoderma edule (Mollusca, Bivalvia) in the Marennes-Oléron Bay. Hydrobiologia 440: 317-329

Strasser M, Dekker R, Essink K, Günther CP and 5 others (2003) How predictable is high bivalve recruitment in the Wadden Sea after a severe winter? J Sea Res 49:47-57

Van der Meer J, Piersma T, Beukema JJ (2001a) Population dynamics of benthic species on tidal flats: the possible roles of shorebird predation. Ecol Stud 151:317-335

Van der Meer J, Beukema JJ, Dekker R (2001b) Long-term variability in secondary production of an intertidal bivalve population is primarily a matter of recruitment variability. J Anim Ecol 70:159-169

Van Stralen MR (1990) Het kokkelbestand in de Oosterschelde en de Waddenzee in 1990. RIVO Rapport, AQ 90-03, p 1-47

Warwick RM, Price R (1975) Macrofauna production in an estuarine mud-flat. J Mar Biol Assoc UK 55:1-18

Wolff WJ, De Wolf L (1977) Biomass and production of zoobenthos in the Grevelingen estuary, the Netherlands. Estuar Coast Mar Sci 5:1-24

Zwarts L (1991) Seasonal variation in body weight of the bivalves Macoma balthica, Scrobicularia plana, Mya arenaria and Cerastoderma edule in the Dutch Wadden Sea. Neth J Sea Res 28:231-245

Submitted: February 18, 2005; Accepted: September 7, 2005 Proofs received from author(s): February 15, 2006 